FORTES, Larissa Borges. A sustentabilidade e o pluralismo jurídico como principais elementos do novo constitucionalismo latino-americano. Revista Eletrônica Direito e Política, Programa de PósGraduação Stricto Sensu em Ciência Jurídica da UNIVALI, Itajaí, v.12, n.3, 30 quadrimestre de 2017. Disponível em: www.univali.br/direitoepolitica - ISSN 1980-7791

\title{
A SUSTENTABILIDADE E O PLURALISMO JURÍDICO COMO PRINCIPAIS ELEMENTOS DO NOVO CONSTITUCIONALISMO LATINO-AMERICANO
}

\author{
SUSTAINABILITY AND LEGAL PLURALISM AS MAIN ELEMENTS OF THE NEW \\ LATIN AMERICAN CONSTITUTIONALISM
}

\section{Larissa Borges Fortes ${ }^{1}$}

SUMÁRIO: Introdução; 1 O pluralismo jurídico e o resgate dos saberes dos povos originários enquanto características para o surgimento do novo constitucionalismo latino-americano; 20 que aprender com as Constituições da Bolívia e do Equador? Apontamentos sobre a Importância do reconhecimento dos Direitos da Natureza e da Plurinacionalidade enquanto pressupostos da Sustentabilidade; Considerações finais; Referências das fontes citadas

\section{RESUMO}

Pioneiramente, a Bolívia se estabeleceu enquanto Estado Plurinacional e, o Equador incluiu em sua nova Constituição questões significativas no âmbito dos direitos indígenas, o que representa um marco no novo Constitucionalismo Latino-Americano, concretizando um ideal de pluralismo étnico-cultural e jurídico. Estabeleceu-se um verdadeiro giro descolonial e ecocêtrico, resgatando os saberes tradicionais e o paradigma do bem viver. A Constituição equatoriana, também na vanguarda, estabeleceu os Direitos da Natureza ou Pachamama como pressuposto de Sustentabilidade. Diante desses novos elementos, buscouse responder ao seguinte problema de pesquisa: Quais os fundamentos que o Constitucionalismo Latino-Americano traz como inovação para caminhar no horizonte da Sustentabilidade? Através do método de pesquisa indutivo e da técnica de pesquisa bibliográfica, procurou-se responder ao problema verificando as contribuições das Constituições da Bolívia e do Equador para a composição de uma perspectiva plural e biocêntrica, através da plurinacionalidade e dos Direitos da Natureza, avaliando como esses fundamentos do cenário Latino-Americano contribuem para que se caminhe no horizonte da Sustentabilidade.

PALAVRAS-CHAVE: Constitucionalismo Latino-americano; Pluralismo Jurídico; Plurinacionalidade; Sustentabilidade; Direitos da Natureza

\footnotetext{
1 Especialista em Direito do Trabalho e Processo do Trabalho pela Faculdade Meridional - IMED. Mestranda em Direito pela Faculdade Meridional - IMED, na linha de pesquisa "Fundamentos do Direitos e da Democracia". Membro do grupo de pesquisa Ética, Cidadania e Sustentabilidade, sob orientação do Prof. Dr. Sergio Ricardo Fernandes de Aquino. Bolsista CAPES/PROSUP. Passo Fundo. RS. Brasil. Currículo Lattes: http://lattes.cnpq.br/6228368628395288 - E-mail: lari_bf@yahoo.com.br
} 
FORTES, Larissa Borges. A sustentabilidade e o pluralismo jurídico como principais elementos do novo constitucionalismo latino-americano. Revista Eletrônica Direito e Política, Programa de PósGraduação Stricto Sensu em Ciência Jurídica da UNIVALI, Itajaí, v.12, n.3, 30 quadrimestre de 2017. Disponível em: www.univali.br/direitoepolitica - ISSN 1980-7791

\section{ABSTRACT}

Precursory, Bolivia and Ecuador settled as Plurinational States, landmark in the new Latin American Constitutionalism, concretizing an ideal of ethno-cultural and legal pluralism. Established a true decolonial and ecocentric turning, rescuing traditional knowledges and the "right living" paradigm. The Ecuadorian Constitution also at the forefront, established the Rights of Nature or Pachamama as Sustainability assumptions. In view of these new elements, sought to answer the following research problem: Which fundamentals Constitutionalism Latin American brings like innovations to look in Sustainability horizon? Through the inductive research method and technique of literature reserch, sought to respond to the problem by checking the contributions of the constitutions of Bolivia and Ecuador to the composition of a plural and biocentric perspective, through the plurinationality and of Nature's Rights, evaluating how these fundamentals of the Latin American scenario can contribute to walk in Sustainability horizon.

KEYWORDS: Latin American Constitutionalism. Legal Pluralism. Plurinationality. Sustainability. Nature's Rights.

\section{INTRODUÇÃo}

O novo constitucionalismo latino-americano se apresenta com elementos inovadores e fundamentais para uma transformação dos países que compõe esse movimento. O referido movimento já nasce de forma muito interessante, na medida em que é fruto de inúmeras lutas populares, movimentos sociais, populações indígenas, sociedade civil organizada.

Ou seja, o processo constituinte do movimento que compõe o novo constitucionalismo latino-americano nasce num cenário de plena participação popular, com uma composição de vozes que até estão estavam apagadas ou esquecidas.

Muitos teóricos chegam a denominar o novo constitucionalismo latino americano como constitucionalismo democrático ou emancipatório, dada a forma como nasceu: para atender aos anseios dos povos e comunidades excluídos desses processos, herança do período colonial.

Com o nascimento do novo constitucionalismo latino-americano, renasceram saberes esquecidos ou encobertos, como os saberes dos povos indígenas andinos, através do paradigma do buen vivir ou vivir bien. Tal cosmovisão 
FORTES, Larissa Borges. A sustentabilidade e o pluralismo jurídico como principais elementos do novo constitucionalismo latino-americano. Revista Eletrônica Direito e Política, Programa de PósGraduação Stricto Sensu em Ciência Jurídica da UNIVALI, Itajaí, v.12, n.3, 30 quadrimestre de 2017. Disponível em: www.univali.br/direitoepolitica - ISSN 1980-7791

propõe um reencontro do ser humano com a Mãe Terra (Pachamama) ou Natureza, buscando percorrer um caminho no horizonte da Sustentabilidade.

Nesse passo, o presente trabalho procurou responder ao seguinte problema de pesquisa: Quais os fundamentos que o Constitucionalismo Latino-Americano traz como inovação para caminhar no horizonte da Sustentabilidade?

Para responder o referido problema, o presente trabalho foi divido em dois tópicos. O primeiro tópico procurará tratar do pluralismo jurídico e o resgate dos saberes indígenas como fundamentos do novo constitucionalismo latinoamericano.

Nesse tópico será abordada a cosmovisão andina e como tal filosofia propõe uma mudança em estilos de vida, mudança do próprio modelo de Estado, o que corresponde a uma verdadeira alternativa aos processos desenvolvimentistas propostos pela visão ocidental.

Além disso, abordará como se deu a concretização do pluralismo jurídico, fundamental para que se garanta a coexistência de vários saberes. Estudar-se-á a necessidade de um giro descolonial, com o resgate dos saberes dos povos originários, até então excluídos dos textos normativos.

No segundo e último tópico será abordados de que forma as Constituições da Bolívia e do Equador, enquanto precursoras no que tange ao reconhecimento da plurinacionalidade e estabelecimento de Direitos da Natureza ou Pachamama, contribuíram para a construção do novo constitucionalismo latino-americano.

Abordará, inclusive, se tais elementos inovadores decorrentes de novo movimento poderão ser considerados enquanto pressupostos da mudança de paradigma e pressupostos da Sustentabilidade.

Nesse sentido, serão analisados alguns artigos contidos nas Constituições da Bolívia e Equador, procurando-se verificar se tais direitos ali contidos são, de fato, imprescindíveis para a construção de um constitucionalismo preocupado em caminhar no horizonte da Sustentabilidade. 
FORTES, Larissa Borges. A sustentabilidade e o pluralismo jurídico como principais elementos do novo constitucionalismo latino-americano. Revista Eletrônica Direito e Política, Programa de PósGraduação Stricto Sensu em Ciência Jurídica da UNIVALI, Itajaí, v.12, n.3, 30 quadrimestre de 2017. Disponível em: www.univali.br/direitoepolitica - ISSN 1980-7791

\section{O PLURALISMO JURÍdico E O RESGATE dOS SABERES DOS POVOS ORIGINÁRIOS ENQUANTO CARACTERÍSTICAS PARA O SURGIMENTO DO NOVO CONSTITUCIONALISMO LATINO-AMERICANO}

A cosmovisão ou visão cósmica seria a forma particular, de cada povo, de sentir/perceber e projetar o mundo. Existem inúmeros povos na região andina, cada qual com sua cosmovisão, no entanto, apesar de cada um possuir sua própria identidade, há uma característica essencial que é comum a todos esses povos: o paradigma comunitário baseado na vida em harmonia e equilíbrio com o entorno. Recuperar essa cosmovisão é voltar a sua identidade, é entrar em contato com a cosmovisão de seus ancestrais.

Entender a cosmovisão andina é entender como se pretende o novo constitucionalismo latino-americano, a partir do buen vivir/vivir bien. A expressão que em Aymara (Bolívia) é conhecida como "Suma Qamaña" (vivir bien) e em Quechua (Equador) é conhecida como "Sumak Kawsay" (buen vivir), que significam ${ }^{2}$ viver em plenitude.

Ou seja, significam viver em harmonia e equilíbrio; em harmonia com os ciclos da Mãe Terra (Pachamama), com o cosmos, com a vida e a história e, principalmente, em equilíbrio com toda forma de existência - humana e não humana, em permanente e mútuo respeito.

A identidade desses povos nasce de uma profunda relação com o entorno, com a Mãe Terra, com o lugar que habitam. Nasce, também, de acordo com a forma de vida, com o idioma, as danças, a música, etc. Existe uma identidade natural, que nasce de uma complementação com a comunidade da vida.

A partir da significação da expressão "cosmovisão", mostra-se imprescindível que seja distinguido o "viver bem" do "vivir mejor". Quando se analisa o "viver melhor", pressupõe-se que alguém vive "pior". Nesse sentido, segundo a Filosofia Andina, essa competição de quem vive melhor acabou por gerar uma

\footnotetext{
2 Traduzir o significado das expressões em Aymara e Quechua é muito difícil, na medida em que tais expressões são muito próprias e cheias de significados em suas próprias origens. A tradução, inevitavelmente, acaba perdendo um pouco de seu significado original.
} 
FORTES, Larissa Borges. A sustentabilidade e o pluralismo jurídico como principais elementos do novo constitucionalismo latino-americano. Revista Eletrônica Direito e Política, Programa de PósGraduação Stricto Sensu em Ciência Jurídica da UNIVALI, Itajaí, v.12, n.3, 30 quadrimestre de 2017. Disponível em: www.univali.br/direitoepolitica - ISSN 1980-7791

sociedade cada vez mais desigual, desequilibrada, depredadora, consumista, insensível, antropocêntrica e antinatural.

Percebe-se que a sociedade atual, em aspecto global, necessita se conectar a novas formas de percepção de mundo e de estilo de vida que, ao que parece, a cosmovisão andina tem muito a ensinar à civilização ocidental.

Nesse sentido, as bases legais que se preocupam em manter/resgatar a Filosofia Andina e a cultura do vivir bien/buen vivir se mostram valiosas, além de precursoras de um movimento que pretende auxiliar na construção de um novo modelo de sociedade.

Para essa construção, a questão da plurinacionalidade é de enorme importância, na medida em que reconhece e valoriza a existência de vários povos, várias nacionalidades, várias identidades, dentro de um mesmo território. A plurinacionalidade vem para resgatar as identidades dilaceradas pelas forças colonizadoras. Assim também referem Wolkmer e Fagundes ${ }^{3}$ :

No processo da refundação plurinacional do Estado, vale ter presente a condição de pluriculturalidade existente, negada e encoberta pelo processo de colonização, forjada no seio dos interesses patrimoniais das elites dirigentes, em que a fundamentação violenta reformulava-se no tempo para seguir hegemônica. $O$ alto grau de complexidade das relações sociais não pode mais ser sufocado pela racionalidade positiva e reducionista, mas direcionar-se para a racionalidade emancipatória ou, ainda, de libertação, embasada na crítica como movimento de construção da nova realidade edificada por aqueles que sempre tiveram os espaços de poder e decisão negados.

Nesse mesmo sentido assinala Proner ${ }^{4}$, indicando que a plurinacionalidade é um marco no constitucionalismo da América Latina para o enfrentamento necessário

3 WOLKMER, Antônio Carlos, FAGUNDES, Lucas Machado. Tendências contemporâneas do constitucionalismo latino-americano: Estado plurinacional e pluralismo jurídico. In: Pensar, Fortaleza, v. 16, n. 2, p. 371-408, jul./dez. 2011, p. 393-394.

4 PRONER, Carol. O Estado Plurinacional e a Nova Constituição Boliviana: Contribuições da experiência boliviana ao debate dos limites ao modelo democrático liberal. In: WOLKMER, Antônio Carlos. Constitucionalismo latino-americano: tendências contemporâneas. Curitiba: Juruá, 2013, p. 143-144. 
FORTES, Larissa Borges. A sustentabilidade e o pluralismo jurídico como principais elementos do novo constitucionalismo latino-americano. Revista Eletrônica Direito e Política, Programa de PósGraduação Stricto Sensu em Ciência Jurídica da UNIVALI, Itajaí, v.12, n.3, 30 quadrimestre de 2017. Disponível em: www.univali.br/direitoepolitica - ISSN 1980-7791

ao modelo de Estado hegemônico - completamente contrário à Filosofia Andina e o paradigma do buen vivir/vivir bien:

A decisão de construir um documento jurídico fundante da sociedade boliviana com o reconhecimento da plurinacionalidade é um fato inovador por sua capacidade de enfrentamento ao modelo de Estado hegemônico (o modelo de Estado-Nação de corte liberal defendido pelos setores sociais conservadores em aliança com os liberais), mas principalmente pela forma que se produziu a mudança, a participação do sujeito coletivo, dos movimentos sociais, partidos políticos de esquerda e representantes das nações indígenas que jamais participaram significativamente das instituições e instâncias decisórias do Estado (Pacto da Unidade).

Rememora-se a Conferência Geral da OIT (1989), onde foi aprovado um documento que reconhece as pretensões dos povos indígenas, no sentido de assumir o controle de suas próprias instituições e formas de vida, de desenvolvimento econômico, mantendo e fortalecendo as suas identidades, línguas e religião, dentro do marco dos Estados em que vivem.

Outro documento importante foi a Declaração das Nações Unidas sobre os Direitos dos Povos Indígenas, aprovada em 7 de setembro de 2007, na Assembleia Geral das Nações Unidas. O Art. 30, da referida Declaração, assim prevê: "os povos indígenas têm o direito à livre determinação. Em virtude desse direito, decidem livremente sua condição política e perseguem livremente seu desenvolvimento social e cultural".

A partir dos anos setenta, as principais organizações indígenas iniciaram discussões acerca da formação de estados plurinacionais em substituição aos estados uninacionais, que se mostravam na perspectiva excludente. Os estados constituídos de forma "uninacional" somente reconhecem a cultura ocidental, promovendo processos de homogeneização e aculturação, contribuindo para a marginalização dos povos indígenas.

Em 2008 e 2009, as primeiras Constituições Plurinacionais do Equador e da Bolívia, respectivamente, foram promulgadas. A partir dos anos 90 é que se 
FORTES, Larissa Borges. A sustentabilidade e o pluralismo jurídico como principais elementos do novo constitucionalismo latino-americano. Revista Eletrônica Direito e Política, Programa de PósGraduação Stricto Sensu em Ciência Jurídica da UNIVALI, Itajaí, v.12, n.3, 30 quadrimestre de 2017. Disponível em: www.univali.br/direitoepolitica - ISSN 1980-7791

começa a iniciar um verdadeiro processo de estabelecimento de estratégias para a construção de estados plurinacionais. Ressalta-se que, desses processos de criação dos estados plurinacionais, muitos massacres e perseguições ocorreram contra os povos indígenas, por parte da classe dominante - colonizadores contemporâneos.

Os movimentos do constitucionalismo surgidos para compor o novo cenário na América Latina foram de extrema importância, na medida em que provocam verdadeira revolução na lógica européia imposta a estes países. Na mesma esteira refere Wolkmer e Fagundes ${ }^{5}$ :

Importa mostrar como os movimentos do constitucionalismo ocorrido recentemente em países sul-americanos (Bolívia, Equador e Venezuela) tentam romper com a lógica liberalindividualista das constituições políticas tradicionalmente operadas, reinventando o espaço público a partir dos interesses e necessidades das maiorias alijadas historicamente dos processos decisórios. Assim, as novas constituições surgidas no âmbito da América Latina são do ponto de vista da filosofia jurídica, uma quebra ou ruptura com a antiga matriz eurocêntrica de pensar o Direito e o Estado para o continente, voltando-se, agora, para refundação das instituições, a transformação das idéias e dos instrumentos jurídicos em favor dos interesses e das culturas encobertas e violentamente apagadas da sua própria história; quiçá, observa-se um processo de descolonização do poder e da justiça.

Inicia-se o processo de alteração constitucional na Colômbia e Venezuela, sendo estas as precursoras nesse movimento do novo constitucionalista latinoamericano, na medida em que já trazem importantes alterações legislativas. No entanto, o presente estudo se restringirá a analisar as Constituições da Bolívia e do Equador, principalmente por conta das questões acerca da plurinacionalidade e dos direitos da Natureza, inovações trazidas especialmente por estas duas constituições.

5 WOLKMER, Antônio Carlos, FAGUNDES, Lucas Machado. Tendências contemporâneas do constitucionalismo latino-americano: Estado plurinacional e pluralismo jurídico. In: Pensar, Fortaleza, v. 16, n. 2, p. 371-408, jul./dez. 2011, p. 377-378. 
FORTES, Larissa Borges. A sustentabilidade e o pluralismo jurídico como principais elementos do novo constitucionalismo latino-americano. Revista Eletrônica Direito e Política, Programa de PósGraduação Stricto Sensu em Ciência Jurídica da UNIVALI, Itajaí, v.12, n.3, 30 quadrimestre de 2017. Disponível em: www.univali.br/direitoepolitica - ISSN 1980-7791

Em verdade, Wolkmer e Fagundes ${ }^{6}$ chegam a indicar a existência de uma espécie de ciclos do novo constitucionalismo latino-americano insurgente, sendo que o primeiro ciclo teria iniciado com as Constituições do Brasil (1988) e da Colômbia (1991), o segundo ciclo com a Constituição da Venezuela (1999) e o terceiro ciclo com as Constituições do Equador (2008) e da Bolívia (2009). Já podemos visualizar um quarto ciclo nesse processo, com a nova Constituição do Chile, que já anunciou - em 2015 - estar caminhando para um novo processo constituinte.

No caso do Equador, a Assembleia Constituinte do Estado Político do Equador foi formada em 6 de agosto de 2006. De acordo Mamani7, setores da extrema direita tentaram deter a formação da referida Assembleia Constituinte, promovendo humilhações e perseguições racistas, a exemplos o massacre de 24 de maio de 2008, em Sucre e o massacre em Porvenir (Pando), em setembro de 2008.

A forma como ocorreram as discussões em torno da Constituição Política do Equador também não foram nada fáceis. Em 1990, a Confederação de Nacionalidades Indígenas do Equador (CONAIE), já havia solicitado a alteração do Art. 10, da Constituição do Equador, para que o Estado se declarasse um estado plurinacional.

Apesar das pressões e tensões, na tentativa de desestabilizar e desarticular os movimentos indígenas, estes conseguiram, em 2008, a promulgação da nova Constituição Política do Equador. Em seu preâmbulo ${ }^{8}$, assim está previsto:

RECONOCIENDO nuestras raíces milenarias, forjadas por mujeres y hombres de distintos pueblos, CELEBRANDO a la naturaleza, la Pacha Mama, de la que somos parte y que es vital para nuestra existencia, INVOCANDO el nombre de Dios

6 WOLKMER, Antônio Carlos, FAGUNDES, Lucas Machado. Tendências contemporâneas do constitucionalismo latino-americano: Estado plurinacional e pluralismo jurídico. In: Pensar, Fortaleza.

7 MAMANI, Fernando H. Buen vivir/ Vivir bien: Filosofía, políticas, estrategias y experiencias regionales andinas. Peru: CAOI, 2010.

8 CONSTITUICIÓN DE LA REPÚBLICA DEL ECUADOR. Disponível em: <http://www.stf.jus.br/repositorio/cms/portalStfInternacional/newsletterPortalInternacionalFoco/a nexo/ConstituicaodoEquador.pdf>. Acesso em 29 set 2015. 
FORTES, Larissa Borges. A sustentabilidade e o pluralismo jurídico como principais elementos do novo constitucionalismo latino-americano. Revista Eletrônica Direito e Política, Programa de PósGraduação Stricto Sensu em Ciência Jurídica da UNIVALI, Itajaí, v.12, n.3, 30 quadrimestre de 2017. Disponível em: www.univali.br/direitoepolitica - ISSN 1980-7791

y reconociendo nuestras diversas formas de religiosidad $y$ espiritualidad, APELANDO a la sabiduría de todas las culturas que nos enriquecen como sociedad, COMO HEREDEROS de las luchas sociales de liberación frente a todas las formas de dominación y colonialismo,

$Y$ con un profundo compromiso con el presente y el futuro, Decidimos construir Una nueva forma de convivencia ciudadana, en diversidad y armonía con la naturaleza, para alcanzar el buen vivir, [...].

Nessa nova Constituição do Equador, considerando o horizonte de viver bem, com olhar sobre o equilíbrio da Pachamama, há uma série de artigos que apontam o direito das populações a viver em um ambiente saudável e ecologicamente equilibrado, garantindo a Sustentabilidade e o viver bem.

Já em 7 de fevereiro de 2009, foi promulgada a Constituição do Estado Plurinacional da Bolívia, estabelecendo finalidades e funções que orientam as políticas públicas no horizonte do "vivir bien". Assim passou a constar na nova Constituição da Bolívia, em seu preâmbulo:

En tiempos inmemoriales se erigieron montañas, se desplazaron ríos, se formaron lagos. Nuestra amazonia, nuestro chaco, nuestro altiplano y nuestros llanos y valles se cubrieron de verdores y flores. Poblamos esta sagrada Madre Tierra con rostros diferentes, y comprendimos desde entonces la pluralidad vigente de todas lãs cosas y nuestra diversidad como seres y culturas. Así conformamos nuestros pueblos, y jamás comprendimos el racismo hasta que 10 sufrimos desde los funestos tiempos de la colonia.

El pueblo boliviano, de composición plural, desde la profundidad de la historia, inspirado en las luchas del pasado, en la sublevación indígena anticolonial, en la independencia, en las luchas populares de liberación, en las marchas indígenas, sociales y sindicales, en lãs guerras del agua y de octubre, en las luchas por la tierra y territorio, y con la memoria de nuestros mártires, construimos un nuevo Estado.

Un Estado basado en el respeto e igualdad entre todos, con princípios de soberanía, dignidad, complementariedad, solidaridad, armonía y equidad en la distribución y redistribución del producto social, donde predomine la búsqueda del vivir bien; con respeto a la pluralidad 
FORTES, Larissa Borges. A sustentabilidade e o pluralismo jurídico como principais elementos do novo constitucionalismo latino-americano. Revista Eletrônica Direito e Política, Programa de PósGraduação Stricto Sensu em Ciência Jurídica da UNIVALI, Itajaí, v.12, n.3, 30 quadrimestre de 2017. Disponível em: www.univali.br/direitoepolitica - ISSN 1980-7791

económica, social, jurídica, política y cultural de los habitantes de esta tierra; en convivencia colectiva con acceso al agua, trabajo, educación, salud y vivienda para todos.

Dejamos en el pasado el Estado colonial, republicano y neoliberal. Asumimos el reto histórico de construir colectivamente El Estado Unitario Social de Derecho Plurinacional Comunitario, que integra y articula los propósitos de avanzar hacia una Bolivia democrática, productiva, portadora e inspiradora de la paz, comprometida con el desarrollo integral y con la libre determinación de los pueblos.

Nosotros, mujeres y hombres, a través de la Asamblea Constituyente y con el poder originario del pueblo, manifestamos nuestro compromiso con la unidad e integridad del país. Cumpliendo el mandato de nuestros pueblos, con la fortaleza de nuestra Pachamama y gracias a Dios, refundamos Bolivia.

Honor y gloria a los mártires de la gesta constituyente y liberadora, que han hecho posible esta nueva historia.

Ainda que a população da Bolívia seja predominantemente indígena ou mestiça, é completamente inovador o reconhecimento contido na Constituição do Estado Plurinacional da Bolívia, já que os povos originários da América Latina tiveram seus direitos negados ao longo da história, sendo-lhes imposto um "modelo" vindo diretamente do continente europeu, a partir da visão de mundo próprias daquele continente.

Com o reconhecimento do estado plurinacional há um verdadeiro resgate das bases culturas e sabedorias encobertas pelos colonizadores, passando a existir espaços para todos os diferentes que vivem sob um mesmo território. O Art. $8^{\circ}$, da Constituição Plurinacional da Bolívia ${ }^{9}$, assim também prevê:

I El Estado asume y promueve como principios éticomorales de la sociedad plural: ama qhilla, ama llulla, ama suwa (no seas flojo, no seas mentiroso ni seas ladrón), suma qamaña (vivir bien), ñandereko (vida armoniosa), teko

9 CONSTITUICIÓN POLÍTICA DEL ESTADO PLURINACIONAL DE BOLIVIA. Disponível em: <http://www.gacetaoficialdebolivia.gob.bo/edicions/buscar>. Acesso em 31 maio 2015. 
FORTES, Larissa Borges. A sustentabilidade e o pluralismo jurídico como principais elementos do novo constitucionalismo latino-americano. Revista Eletrônica Direito e Política, Programa de PósGraduação Stricto Sensu em Ciência Jurídica da UNIVALI, Itajaí, v.12, n.3, 30 quadrimestre de 2017. Disponível em: www.univali.br/direitoepolitica - ISSN 1980-7791

kavi (vida buena), ivi maraei (tierra sin mal) y qhapaj ñan (camino o vida noble).

II El Estado se sustenta en los valores de unidad, igualdad, inclusión, dignidad, libertad, solidaridad, reciprocidad, respeto, complementariedad, armonía, transparencia, equilibrio, igualdad de oportunidades, equidad social y de género en la participación, bienestar común, responsabilidad, justicia social, distribución y redistribución de los productos y bienes sociales, para vivir bien.

A nova constituição da Bolívia prevê a promoção de uma cultura de paz, sempre velando pelo equilíbrio da Pachamama ou Mãe Terra, com o horizonte no "vivir bien", ou seja, na plenitude, no equilíbrio e harmonia, no caminho da Sustentabilidade.

Nota-se que a previsão e garantia de um estado plurinacional funciona como mola propulsora para o desenvolvimento de questões decorrentes da própria Filosofia Andina, tais como o equilíbrio, a harmonia e, principalmente, a Sustentabilidade.

Enquanto a cosmovisão andina propõe a cooperação, o afeto, a reciprocidade e, principalmente, o equilíbrio com a Pachamama (Mãe Terra), a visão ocidental propõe a exploração sem limites, cultivando - através de suas práticas mercantis, inclusive, aquilo que a história nos mostra de mais cruel - se for pensado na perspectiva de humanidade -: a escravidão.

A visão ocidental propõe a competição, a obtenção de lucros, sem medir as conseqüências para as conquistas que se propõe, seja ela com relação aos trabalhadores envolvidos, seja com relação ao meio ambiente que se põe cada vez mais degradado e em desequilíbrio. Boff ${ }^{10}$ bem examina a questão da visão ocidental acerca do meio ambiente e dos meios de produção

Para esse tipo de economia do crescimento, a natureza é degradada à condição de um simples conjunto de recursos naturais, ou matéria-prima, disponível aos interesses humanos particulares. Os trabalhadores são considerados recursos humanos ou, pior ainda, material humano, em

10 BOFF, Leonardo. Ética da vida: a nova centralidade. Rio de Janeiro: Record, 2009, p. 23. 
FORTES, Larissa Borges. A sustentabilidade e o pluralismo jurídico como principais elementos do novo constitucionalismo latino-americano. Revista Eletrônica Direito e Política, Programa de PósGraduação Stricto Sensu em Ciência Jurídica da UNIVALI, Itajaí, v.12, n.3, 30 quadrimestre de 2017. Disponível em: www.univali.br/direitoepolitica - ISSN 1980-7791

função de uma meta de produção. Como se depreende, a visão é instrumental e mecanicista: pessoas, animais, plantas, minerais, enfim, todos os seres perdem o seu valor intrínseco e sua autonomia relativa. São reduzidos a meros meios para um fim fixado subjetivamente pelo ser humano, que se considera o centro e o rei do universo.

Pois é justamente com o pluralismo jurídico que se pode compreender, dentre de um mesmo elenco de direitos, saberes de todos os povos que comungam da mesma constituição. O pluralismo jurídico vem, também, como uma das principais características desse novo constitucionalismo latino-americano.

A imposição de um modelo de Estado ao estilo europeu e de uma forma de conceber o direito, mostrava-se autoritária, excludente e mantida apenas para atender aos interesses das elites herdeiras do período colonial. Os povos originários da América Latina - por longo tempo - foram deixados de lado, sem qualquer possibilidade de participação nas decisões política e, consequentemente, sem ver seus direitos garantidos. Nesse sentido, é o que nos rememora Wolkmer e Fagundes ${ }^{11}$ :

Sendo assim, a insurgência política, nos Andes e na Venezuela, demonstra uma postura de rompimento e transformação do paradigma estatal dominante; a partir da historicidade crítica, os sujeitos que foram coisificados e moldados à racionalidade externa homogeneizadora emergem no cenário político de exigibilidade das suas necessidades fundamentais, tomando $o$ poder sob as variantes da mentalidade voltada aos interesses populares e com vista a absorver as complexidades, sem, contudo, uniformizá-las.

O processo constituinte latino-americano, nesse novo cenário, trouxe um alento aos corações desesperançosos com as mudanças em termos de desigualdades e com os rumos para os quais os modelos de estado ao estilo europeu e norteamericano estão levando os países colonizados por estes.

\footnotetext{
11 WOLKMER, Antônio Carlos, FAGUNDES, Lucas Machado. Tendências contemporâneas do constitucionalismo latino-americano: Estado plurinacional e pluralismo jurídico. In: Pensar, Fortaleza, p. 392.
} 
FORTES, Larissa Borges. A sustentabilidade e o pluralismo jurídico como principais elementos do novo constitucionalismo latino-americano. Revista Eletrônica Direito e Política, Programa de PósGraduação Stricto Sensu em Ciência Jurídica da UNIVALI, Itajaí, v.12, n.3, 30 quadrimestre de 2017. Disponível em: www.univali.br/direitoepolitica - ISSN 1980-7791

O novo constitucionalismo latino-americano vem para ensinar ao mundo que o direito deve ser construído e pensado por toda coletividade, com a participação de todos os setores, minorias e maiorias, valorizando a diversidade, não a uniformizando. Nesse processo de novas constituições, houve um reacender de luzes dos movimentos sociais, ambientais, mas principalmente, das populações indígenas que tiveram ativa participação na construção de seus próprios direitos.

É a partir dessas novas concepções trazidas com o novo constitucionalismo latino-americano é que se vê concretizar o pluralismo jurídico e a plurinacionalidade. Mais que isso, a partir do constitucionalismo latino-americano insurgente, expressão utilizada por Wolkmer e Fagundes ${ }^{12}$, é possível se pensar em um novo modelo de Estado e de direito, fundamentado na perspectiva da Sustentabilidade, a partir dos direitos da Natureza - um dos grandes legados trazidos com as novas Constituições do Equador e Bolívia, que será estudado no tópico seguinte.

2 O QUE APRENDER COM AS CONSTITUIÇÕES DA BOLÍVIA E DO EQUADOR? APONTAMENTOS SOBRE A IMPORTÂNCIA DO RECONHECIMENTO DOS DIREITOS DA NATUREZA E DA PLURINACIONALIDADE ENQUANTO PRESSUPOSTOS DA SUSTENTABILIDADE

A Sustentabilidade ainda pode ser considerada uma categoria aberta, sem uma definição completamente delineada. No entanto, a partir de alguns autores que escrevem sobre a temática, pode-se concluir que os termos "desenvolvimento sustentável", "economia verde", "crescimento econômico sustentável", dentre tantos outros, não podem ser considerados sinônimos e, talvez, sequer possam ser considerados como designações de práticas efetivamente sustentáveis.

\footnotetext{
12 WOLKMER, Antônio Carlos, FAGUNDES, Lucas Machado. Tendências contemporâneas do constitucionalismo latino-americano: Estado plurinacional e pluralismo jurídico. In: Pensar, Fortaleza.
} 
FORTES, Larissa Borges. A sustentabilidade e o pluralismo jurídico como principais elementos do novo constitucionalismo latino-americano. Revista Eletrônica Direito e Política, Programa de PósGraduação Stricto Sensu em Ciência Jurídica da UNIVALI, Itajaí, v.12, n.3, 30 quadrimestre de 2017. Disponível em: www.univali.br/direitoepolitica - ISSN 1980-7791

Para Bosselmann ${ }^{13}$, a Sustentabilidade é tida enquanto um princípio, devendo possuir um conteúdo normativo,

O princípio da sustentabilidade em si é bem mais definido como o dever de proteger e restaurar a integridade dos sistemas ecológicos da Terra. O conteúdo adicional e as dimensões do princípio serão discutidos mais adiante. Para o nosso propósito presente, deve ficar claro que o princípio tem uma qualidade normativa. É reflexo de uma moral fundamental (o respeito à integridade ecológica), exige uma ação ("proteger e restaurar") e, portanto, pode causar efeito legal. A normatividade de um princípio jurídico precisa ser atendida.

No pensamento de Leff $^{14}$, mostra-se urgente a construção de uma racionalidade ambiental, na medida em que servirá de base transformadora das questões ambientais e alcance da Sustentabilidade. Tal racionalidade ambiental se propõe a analisar as questões de processos de produção/trabalho que contribuem para uma degradação ambiental, transformando a maneira de se pensar tais questões, no sentido de se construir um conjunto de condições econômicas e políticas a partir de princípios do "ecodesenvolovimento", na tentativa de se alcançar um desenvolvimento sustentável e igualitário.

Sobre a necessidade de articular saberes na construção de uma epistemologia ambiental, que caminhe no sentido da Sustentabilidade, Leff ${ }^{15}$ refere que

Isso é necessário sobretudo na perspectiva da construção de uma racionalidade ambiental, que não só assegure condições de sustentabilidade ecológica, mas que gere um potencial ambiental de desenvolvimento a partir dos princípios materiais de uma produtividade cultural, ecológica e tecnológica que gera uma formação socioambiental.

13 BOSSELMANN, Klaus. O princípio da sustentabilidade: transformando direito e governança. Tradução de Phillip Gil França. São Paulo: Editora Revista dos Tribunais, 2015, p. 78.

14 LEFF, Enrique. Epistemologia ambiental. Tradução de Sandra Valenzuela. 5. ed. São Paulo: Cortez, 2011.

15 LEFF, Enrique. Epistemologia ambiental. Tradução de Sandra Valenzuela. p. 120. 
FORTES, Larissa Borges. A sustentabilidade e o pluralismo jurídico como principais elementos do novo constitucionalismo latino-americano. Revista Eletrônica Direito e Política, Programa de PósGraduação Stricto Sensu em Ciência Jurídica da UNIVALI, Itajaí, v.12, n.3, 30 quadrimestre de 2017. Disponível em: www.univali.br/direitoepolitica - ISSN 1980-7791

Já no pensamento de Latouche ${ }^{16}$, a questão ambiental está intimamente ligada às questões econômicas, sendo imprescindível se pensar em mudanças no que se refere ao "crescimento econômico" para se chegar a algumas evoluções no âmbito da Sustentabilidade.

O autor recém citado denomina como decrescimento a forma ideal para se alterar os estilos de vida na modernidade, dando espaço para se pensar - de fato - nas questões ambientais de forma séria. Assim refere Latouche ${ }^{17}$

Ao contrário de uma idéia perversa que não produz necessariamente uma ideia virtuosa, não se trata de preconizar o decrescimento pelo decrescimento, o que seria absurdo; considerando bem, contudo, não o seria nem mais nem menos do que pregar o crescimento pelo crescimento... A palavra de ordem "decrescimento" tem como principal meta enfatizar fortemente o abandono do objetivo do crescimento ilimitado, objetivo cujo motor não é outro senão a busca do lucro por parte dos detentores do capital, com conseqüências desastrosas para o meio ambiente e portanto para a humanidade. Não só a sociedade fica condenada a não ser mais que o instrumento ou o meio da mecânica produtiva, mas o próprio homem tende a se transformar no refugo de um sistema que visa torná-lo inútil e a prescindir dele.

Latouche ${ }^{18}$ complementa, mais adiante, acerca dos limites físicos que o Planeta dispõe, considerando a forma de crescimento que a sociedade atualmente está inserida:

Nosso crescimento econômico excessivo choca-se com os limites da finitude da biosfera. A capacidade de regeneração da Terra já não consegue acompanhar a demanda: o homem transforma os recursos em resíduos mais rápido do que a natureza consegue transformar esses resíduos em novos recursos.

16 LATOUCHE, Sergio. Pequeno tratado do decrescimento sereno. Tradução de Claudia Berliner. São Paulo: Editora WMF Martins Fontes, 2009.

17 LATOUCHE, Sergio. Pequeno tratado do decrescimento sereno. Tradução de Claudia Berliner, p. 04-05.

18 LATOUCHE, Sergio. Pequeno tratado do decrescimento sereno. Tradução de Claudia Berliner, p. 27. 
FORTES, Larissa Borges. A sustentabilidade e o pluralismo jurídico como principais elementos do novo constitucionalismo latino-americano. Revista Eletrônica Direito e Política, Programa de PósGraduação Stricto Sensu em Ciência Jurídica da UNIVALI, Itajaí, v.12, n.3, 30 quadrimestre de 2017. Disponível em: www.univali.br/direitoepolitica - ISSN 1980-7791

Enfim, observam-se as diversas facetas que podem ser concebidas para se chegar a uma definição do que venha a ser Sustentabilidade. Dentre os entendimentos citados anteriormente, acerca do que é Sustentabilidade, verificase algo comum em todos eles: o viés antropocêntrico que carregam.

A partir do cenário latino-americano, principalmente no que tange a Sustentabilidade pensada a partir de conhecimentos advindos dos povos originários da América Latina, observa-se que a referida categoria se mostra mais ampla, centrada na harmonia entre todos os seres que habitam o Planeta.

Aquino $^{19}$ explica a Sustentabilidade a partir da tradição andina, da seguinte forma

A Sustentabilidade, nessa concepção, não pode ser uma expressão antropocêntrica, mas de compreensão biocêntrica. Sustentabilidade é um modo de autoregulação e autopreservação da Terra, independente da ação humana. É a sinfonia entoada, segundo a tradição andina, pela Pacha Mama para cuidar e preservar todos os seres vivos no seu interior. [...]

A partir de tais questões acerca da Sustentabilidade, verifica-se que as Constituições do Equador e da Bolívia trazem grandes avanços, distanciando-se da visão meramente antropocêntrica. Assim refere novamente Aquino ${ }^{20}$

Aos poucos, esse cenário insustentável (e insuportável), modifica-se. A expressão das utopias carregadas de esperança registra-se nos diversos documentos que constituem a intenção de elaborar uma comunidade sulamericana, desde as Constituições do Equador (2008) e Bolívia (2009) até a Declaração Universal dos Direitos da Mae-Terra (Cochabamba, Bolívia, 2010). Os artigos 71 da Constituição do Equador e $8^{\circ}$ da Constituição da Bolívia enunciam essa mudança de paradigma exclusivamente antropocêntrico.

19 AQUINO, Sergio R. F. de. O direito em busca de sua humanidade: diálogos errantes. Curitiba: CRV, 2014, p. 31.

${ }^{20}$ AQUINO, Sergio R. F. de. O direito em busca de sua humanidade: diálogos errantes, p. 32. 
FORTES, Larissa Borges. A sustentabilidade e o pluralismo jurídico como principais elementos do novo constitucionalismo latino-americano. Revista Eletrônica Direito e Política, Programa de PósGraduação Stricto Sensu em Ciência Jurídica da UNIVALI, Itajaí, v.12, n.3, 30 quadrimestre de 2017. Disponível em: www.univali.br/direitoepolitica - ISSN 1980-7791

Tem-se, portanto, que há uma construção desde a América Latina, acerca da temática Sustentabilidade, preocupada em resgatar saberes dos povos indígenas originários, contemplando duas questões de extrema importância para uma mudança de paradigma: plurinacionalidade e, a partir da Filosofia Andina, os direitos da Natureza ou Pachamama.

Importante destacar o papel dos movimentos sociais na América Latina, principalmente nos casos do Equador e da Bolívia, onde tiveram enorme participação nos processos constituintes de tais países, bem como na construção dos textos legais das atuais constituições.

A participação dos movimentos sociais e populações indígenas em tais processos foi fundamental, na medida em que se questionou as políticas neoliberais e a consequente precarização evolutiva da vida das populações mais pobres.

Questionaram, ainda, a realidade dos povos originários e a necessidade de se efetivar políticas pensadas a partir do pluralismo, colocando em debate, com isso, a relação que o atual modelo de sociedade tem com a Natureza e, a partir de suas cosmovisões, a relação que se tem com a Mãe Terra.

Em tais debates, a Filosofia Andina e o paradigma do Buen Vivir/Vivir Bien surgem como uma alternativa, desde os povos latino-americanos, ao desenvolvimento, bem como a Natureza, enquanto sujeito de direitos, surge como alternativa ao antropocentrismo fundante da sociedade atual.

Gudynas $^{21}$ indica um caminho inevitável a ser percorrido para se chegar à Sustentabilidade: superar o antropocentrismo e caminhar no sentido do biocentrismo. Segundo o referido autor, no atual modelo de desenvolvimento que pressupõe o necessário crescimento econômico - há uma apropriação da Natureza pelos seres humanos, enquanto recurso.

21 GUDYNAS, Eduardo. Derechos de la naturaliza: ética biocéntrica y políticas ambientales. Lima: CLAES, 2014. 
FORTES, Larissa Borges. A sustentabilidade e o pluralismo jurídico como principais elementos do novo constitucionalismo latino-americano. Revista Eletrônica Direito e Política, Programa de PósGraduação Stricto Sensu em Ciência Jurídica da UNIVALI, Itajaí, v.12, n.3, 30 quadrimestre de 2017. Disponível em: www.univali.br/direitoepolitica - ISSN 1980-7791

Gudynas $^{22}$ vai além, explica que o esquema antropocêntrico ocorre justamente na necessidade - criada pelo homem - de se buscar uma utilidade do ambiente, de maneira a manipular, explorar, controlar. Nesse passo, tem-se que a crise ambiental ocorre da superexploração dos recursos naturais e da minimização dos seus efeitos.

Ainda, Gudynas ${ }^{23}$ relata que no antropocentrismo os seres humanos estão situados em um lugar privilegiado, sendo concebidos como únicos seres com capacidade de cognição e com capacidade de conferir valores. O referido autor ${ }^{24}$ aduz, ainda, que os efeitos do antropocentrismo utilitarista se irradiam, no seguinte sentido

[...] la insistencia en la utilidad se difunde culturalmente, invade lãs interacciones sociales, y corroe las culturas tradicionales de campesinos e indígenas. Poco a poço ellos también pasan a prestar cada vez más atención a los criterios de beneficios y utilidad.

Por tais razões é que se mostra imprescindível pensar na Sustentabilidade a partir do biocentrismo. Consequentemente, quando se observa os saberes tradicionais respeitados e resgatados pelas legislações latino-americanas, voltando-se o olhar - até então antropocêntrico e eurocêntrico - para os ensinamos dos povos originários, mais próximos a uma visão biocêntrica, conclui-se que os caminhos estão sendo percorridos de maneira adequada.

Quando as Constituições do Equador e da Bolívia reconhecem, expressamente, a existência de uma pluralidade de povos habitantes de uma mesma nação, com saberes distintos e valorosos, capazes de alterar o curso da história no que se refere à Sustentabilidade, percebe-se que os caminhos latino-americanos são os mais adequados a serem seguidos.

\footnotetext{
22 GUDYNAS, Eduardo. Derechos de la naturaliza: ética biocéntrica y políticas ambientales.

23 GUDYNAS, Eduardo. Derechos de la naturaliza: ética biocéntrica y políticas ambientales.

${ }^{24}$ GUDYNAS, Eduardo. Derechos de la naturaliza: ética biocéntrica y políticas ambientales, p. 2930.
} 
FORTES, Larissa Borges. A sustentabilidade e o pluralismo jurídico como principais elementos do novo constitucionalismo latino-americano. Revista Eletrônica Direito e Política, Programa de PósGraduação Stricto Sensu em Ciência Jurídica da UNIVALI, Itajaí, v.12, n.3, 30 quadrimestre de 2017. Disponível em: www.univali.br/direitoepolitica - ISSN 1980-7791

Um marco fundamental contido especialmente na Constituição do Equador são as disposições relacionadas aos Direitos da Natureza ou Pachamama, já que preservada a ótica do paradigma do Buen Vivir, determinando especial espaço aos saberes originários. Contribuem, nesse sentido, Morais e Freitas ${ }^{25}$, ao referir que

A mais impactante novidade jurídica na atual constituição equatoriana decorre da possibilidade de que a natureza (Pachamama) seja sujeito de direitos e não mais, objeto. Todos os seres vivos, e não apenas os humanos, como parte da natureza, de igual modo, titularizariam direitos. [...]

Gudynas $^{26}$ adverte que muitos dos conteúdos relacionados aos Direitos da Natureza e também àqueles relacionados ao paradigma do Buen Vivir e povos indígenas, são conteúdos abertos, impondo referências a serem observadas nas legislações complementares/regulamentares.

Salienta-se o cuidado da Constituição do Equador em reconhecer a Natureza e Pachamama à um nível equivalente de importância, suplantando subordinação histórica dos saberes europeus frente aos saberes dos povos indígenas originários. Importante observar a redação do artigo 71, do Título II, Capítulo Sétimo - Derechos de la naturaleza:

Art. 71.- La naturaleza o Pacha Mama, donde se reproduce y realiza la vida, tiene derecho a que se respete integralmente su existencia $y$ el mantenimiento $y$ regeneración de sus ciclos vitales, estructura, funciones y procesos evolutivos.

Toda persona, comunidad, pueblo o nacionalidad podrá exigir a la autoridad pública el cumplimiento de los derechos de la naturaleza. Para aplicar e interpretar estos derechos se observaran los princípios establecidos en la Constitución, en lo que proceda.

\footnotetext{
${ }^{25}$ MORAES, Germana de Oliveira; FREITAS, Raquel Coelho. O novo constitucionalismo latinoamericano e o giro ecocêntrico da Constituição do Equador de 2008: os direitos de Pachamama e o bem viver (sumak kawsay). In: WOLKMER, Antônio Carlos. Constitucionalismo latino-americano: tendências contemporâneas. Curitiba: Juruá, 2013, p. 103-124, p. 116.
}

${ }^{26}$ GUDYNAS, Eduardo. Derechos de la naturaliza: ética biocéntrica y políticas ambientales. 
FORTES, Larissa Borges. A sustentabilidade e o pluralismo jurídico como principais elementos do novo constitucionalismo latino-americano. Revista Eletrônica Direito e Política, Programa de PósGraduação Stricto Sensu em Ciência Jurídica da UNIVALI, Itajaí, v.12, n.3, 30 quadrimestre de 2017. Disponível em: www.univali.br/direitoepolitica - ISSN 1980-7791

El Estado incentivará a las personas naturales y jurídicas, y a los colectivos, para que protejan la naturaleza, y promoverá el respeto a todos los elementos que forman un ecosistema.

Verifica-se uma evidente preocupação em fazer com que coexistam os saberes dos diversos povos habitantes do território equatoriano, seja descendente de europeu, africano ou de outras nacionalidades, seja de qualquer dos povos indígenas, seja de outra nacionalidade. Enfim, o artigo faz questão de fazer menção à Natureza ou Pacha Mama.

O movimento do constitucionalismo latino-americano, especialmente com relação às Constituições da Bolívia e do Equador, quando deslocam o foco da visão ocidental, por consequência, da visão antropocêntrica, dando lugar à Filosofia Andina, estabelecem uma nova percepção dos direitos ali contidos, a partir da visão biocêntrica.

Percebe-se, portanto, que ter reconhecida a questão da plurinacionalidade, estabelecendo direitos a partir da tradição andina do buen vivir/vivir bien, bem como vendo concretizada a questão do pluralismo, tem-se uma enorme mudança de paradigma no movimento das constituições latino-americanas no caminho da Sustentabilidade.

Ainda que somente a Constituição do Equador estabeleça direitos da Natureza, o fato dessas novas constituições latino-americanas (Venezuela, Equador, Bolívia e o Chile, mais recentemente em inícios de processo constituinte) prestarem seu reconhecimento aos saberes dos povos indígenas originários, resgatando o valor da Filosofia Andina, provoca um verdadeiro giro ecocêntrico, fundamental para se pensar a Sustentabilidade em termos mais concretos. Assim também conclui Moraes e Freitas ${ }^{27}$ :

Consolida-se, assim, no campo jurídico-constitucional, no Equador (2008) e também na Bolívia (2009), uma nova visão ecocêntrica, superadora do antropocentrismo, a qual,

27 MORAES, Germana de Oliveira; FREITAS, Raquel Coelho. O novo constitucionalismo latinoamericano e o giro ecocêntrico da Constituição do Equador de 2008: os direitos de Pachamama e o bem viver (sumak kawsay). In: WOLKMER, Antônio Carlos. Constitucionalismo latino-americano: tendências contemporâneas, p. 119. 
FORTES, Larissa Borges. A sustentabilidade e o pluralismo jurídico como principais elementos do novo constitucionalismo latino-americano. Revista Eletrônica Direito e Política, Programa de PósGraduação Stricto Sensu em Ciência Jurídica da UNIVALI, Itajaí, v.12, n.3, 30 quadrimestre de 2017. Disponível em: www.univali.br/direitoepolitica - ISSN 1980-7791

além de admitir a prevalência da cultura da vida, reconhece a indissociável relação de interdependência e complementaridade entre os seres vivos, expressa no valor fundamental da harmonia, desdobrável em valores como unidade, inclusão, solidariedade, reciprocidade, respeito, complementaridade, equilíbrio, destacando-se na constituição equatoriana o reconhecimento expresso dos direitos de Pachamama (da natureza).

Da mesma forma, Alberto Acosta ${ }^{28}$ traz importante contribuição sobre o tema:

La Constitución de Ecuador, pionera en la ruptura de la concepción tradicional de derechos humanos, reconoce por primera vez el derecho de la naturaleza como un derecho autônomo del ser humano. Algunas rupturas conceptuales, comenzando por la denominación. No cabe ya el término genérico de "derechos humanos" para referirse a los derechos que tienen una protección especial en las Constituciones. Conviene denominarlos derechos fundamentaleso derechos constitucionales. Otra ruptura es que la protección a la naturaleza no se la hace porque conviene al ser humano, sino por la naturaleza en sí misma. En consecuencia, la concepción jurídica de los derechos deja de ser antropocéntrica. Tercera ruptura, la teoría jurídica tradicional para entender el derecho tiene que buscar nuevos fundamentos y renovadas lecturas, que tienen que ver con la ruptura del formalismo jurídico y con una superación de la cultura jurídica imperante.

Ao verificar a Constituição do Equador, observa-se um elenco de direitos contidos naquela Carta Política que fazem com que seja considerada pioneira no âmbito das questões ligadas à pluralidade jurídica e direitos da Natureza, por consequência, no caminho da Sustentabilidade.

Já no preâmbulo da referida Constituição está contida a intenção de resgatar suas raízes milenares, bem como os saberes ancestrais, dos diversos povos que habitam o território equatoriano, concretizando, a partir daí, a pluralidade cultural e jurídica. Há a intenção expressa, também, de se reconhecer e seguir os ensinamentos da filosofia andina, a partir do buen vivir ou sumak kawsay.

28 ACOSTA, Alberto; MARTÍNEZ, Esperanza (Org.). La naturaleza con derechos: de la filosofía a la política. Quito, Equador: Ediciones Abya-Yala, 2011, p. 225-226. 
FORTES, Larissa Borges. A sustentabilidade e o pluralismo jurídico como principais elementos do novo constitucionalismo latino-americano. Revista Eletrônica Direito e Política, Programa de PósGraduação Stricto Sensu em Ciência Jurídica da UNIVALI, Itajaí, v.12, n.3, 30 quadrimestre de 2017. Disponível em: www.univali.br/direitoepolitica - ISSN 1980-7791

No Título I, Capítulo Primeiro, artigo $1^{029}$ da referida Constituição, onde são trazidos os princípios fundamentais, está expressa a definição de que o Equador é um Estado plurinacional. Ainda no Título I, no Capítulo Segundo, onde trata dos Ciudadanas y ciudadanos, no artigo 6030, é trazido o reconhecimento efetivo da nacionalidade dos cidadãos equatorianos, sem prejuízo do pertencimento a qualquer dos povos indígenas que coexistem no Estado Plurinacional do Equador.

O Título II, Capítulo Segundo, é destinado exclusivamente aos Derechos del buen vivir, dividido em oito sessões, onde são trazido direitos relacionados à água e alimentação, ambiente saudável, comunicação e informação, cultura e ciência, educação, saúde, habitat e residência e, por fim, trabalho e seguridade social.

Dentre todos os títulos trazidos no referido capítulo, destaca-se no presente trabalho o título que trata do meio ambiente saudável. O artigo $14^{31}$ prevê que as populações tem direito de viverem em um ambiente são e ecologicamente equilibrado, que garanta a sustentabilidade e o buen vivir, sumak kawsay. No mesmo artigo, é declarado que é de interesse público a preservação e conservação, fazendo referência à recuperação de ecossistemas degradados.

Mais adiante, entre os direitos de liberdade e da Natureza, estão dispostos os seguintes artigos, igualmente importantes para o presente estudo: direito a viver

29 Art. 1.- El Ecuador es un Estado constitucional de derechos y justicia, social, democrático, soberano, independiente, unitario, intercultural, plurinacional y laico. Se organiza en forma de república y se gobierna de manera descentralizada.

La soberanía radica en el pueblo, cuya voluntad es el fundamento de la autoridad, y se ejerce a través de los órganos del poder público y de las formas de participación directa previstas en la Constitución.

Los recursos naturales no renovables del territorio del Estado pertenecen a su patrimonio inalienable, irrenunciable e imprescriptible.

30 Art. 6.- Todas las ecuatorianas y los ecuatorianos son ciudadanos y gozarán de los derechos establecidos en la Constitución.

La nacionalidad ecuatoriana es el vínculo jurídico político de las personas con el Estado, sin perjuicio de su pertenencia a alguna de las nacionalidades indígenas que coexisten en el Ecuador plurinacional. [...]

${ }^{31}$ Art. 14.- Se reconoce el derecho de la población a vivir en un ambiente sano y ecológicamente equilibrado, que garantice la sostenibilidad y el buen vivir, sumak kawsay.

Se declara de interés público la preservación del ambiente, la conservación de los ecosistemas, la biodiversidad y la integridad del patrimonio genético del país, la prevención del daño ambiental y la recuperación de los espacios naturales degradados. 
FORTES, Larissa Borges. A sustentabilidade e o pluralismo jurídico como principais elementos do novo constitucionalismo latino-americano. Revista Eletrônica Direito e Política, Programa de PósGraduação Stricto Sensu em Ciência Jurídica da UNIVALI, Itajaí, v.12, n.3, 30 quadrimestre de 2017. Disponível em: www.univali.br/direitoepolitica - ISSN 1980-7791

em um ambiente saudável, ecologicamente equilibrado, livre de contaminação e em harmonia com a Natureza, previsto no artigo $66^{32}$, localizado no Título II, no Capítulo Sexto - Derechos de la liberdad, e no artigo $73^{33}$, já no Título II, Capítulo Sétimo - Derechos de la naturaleza, há referência ao princípio da precaução.

Destaca-se, ainda, além dos direitos elencados anteriormente, a existência de outros tantos direitos, mais próximos aos direitos denominados de terceira geração, tais como: no artigo $15^{34}$, no Titulo II, Capítulo Segundo, onde o Estado deverá promover o uso de tecnologias limpas e energias alternativas, sem contaminação e de baixo impacto, bem como deverá estabelecer a proibição de armas químicas, biológicas e nucleares, as substancias tóxicas e perigosas, resíduos perigosos, organismos geneticamente modificados que representarem riscos. No mesmo artigo, há referência no sentido de que essas obrigações não podem afetar a soberania alimentar ou energética, ou o direito à água.

Outro direito contido na Constituição do Equador, de enorme relevância para a construção de um caminho no horizonte da Sustentabilidade é aquele contido no artigo 5735, Título II, Capítulo Quarto - Derechos de las comunidades, pueblos y

32 Art. 66.- Se reconoce y garantizará a las personas: [...]

27. EI derecho a vivir en un ambiente sano, ecológicamente equilibrado, libre de contaminación y en armonía con la naturaleza.

33 Art. 73.- EI Estado aplicará medidas de precaución y restricción para las actividades que puedan conducir a la extinción de especies, la destrucción de ecosistemas o la alteración permanente de los ciclos naturales. Se prohíbe la introducción de organismos y material orgánico e inorgânico que puedan alterar de manera definitiva el patrimonio genético nacional.

34 Art. 15.- El Estado promoverá, en el sector público y privado, el uso de tecnologías ambientalmente limpias y de energías alternativas no contaminantes y de bajo impacto. La soberanía energética no se alcanzará en detrimento de la soberanía alimentaria, ni afectará el derecho al agua.

Se prohíbe el desarrollo, producción, tenencia, comercialización, importación, transporte, almacenamiento y uso de armas químicas, biológicas y nucleares, de contaminantes orgánicos persistentes altamente tóxicos, agroquímicos internacionalmente prohibidos, y las tecnologías y

agentes biológicos experimentales nocivos y organismos genéticamente modificados perjudiciales para la salud humana o que atenten contra la soberanía alimentaria o los ecosistemas, así como la introducción de residuos nucleares y desechos tóxicos al territorio nacional.

35 Art. 57.- Se reconoce y garantizará a las comunas, comunidades, pueblos y nacionalidades indígenas, de conformidad con la Constitución y con los pactos, convenios, declaraciones y demás instrumentos internacionales de derechos humanos, los siguientes derechos colectivos: [...] 
FORTES, Larissa Borges. A sustentabilidade e o pluralismo jurídico como principais elementos do novo constitucionalismo latino-americano. Revista Eletrônica Direito e Política, Programa de PósGraduação Stricto Sensu em Ciência Jurídica da UNIVALI, Itajaí, v.12, n.3, 30 quadrimestre de 2017. Disponível em: www.univali.br/direitoepolitica - ISSN 1980-7791

nacionalidades, onde traz o direito dos povos, comunidades e nacionalidades com relação à conservação e promoção de práticas de manejo de biodiversidade e de seu entorno natural, assim como condições de consulta e participação na exploração de recursos não renováveis em seus territórios.

De acordo com Gudynas ${ }^{36}$, os direitos de terceira geração são muito importantes e são evoluções, considerando que algumas legislações, até pouco tempo, não possuíam qualquer mecanismo de preservação do meio ambiente. No entanto, segundo o mencionado autor, os direitos de terceira geração ainda apresentam uma perspectiva antropocêntrica.

Nesse passo, segundo Gudynas ${ }^{37}$, quando se tem direitos da Natureza ou Pachamama previstos na Constituição do Equador, considerados como próprios da Natureza, com valores em si mesmos, independente dos valores humanos, pode ser observado tais direitos a partir de uma ótica biocêntrica. Ou seja, juridicamente, a Natureza é considerada sujeito de direitos de forma pioneira.

Há posições que divergem de tal perspectiva, entendendo existir problemas práticos na aplicação de tais direitos, como por exemplo, determinar quem representaria a Natureza nas ações judiciais. Para demonstrar a possibilidade de

7. La consulta previa, libre e informada, dentro de un plazo razonable, sobre planes y programas de prospección, explotación y comercialización de recursos no renovables que se encuentren en sus tierras y que puedan afectarles ambiental o culturalmente; participar en los beneficios que esos proyectos reporten y recibir indemnizaciones por los perjuicios sociales, culturales y ambientales que les causen. La consulta que deban realizar las autoridades competentes será obligatoria y oportuna. Si no se obtuviese el consentimiento de la comunidad consultada, se procederá conforme a la Constitución y la ley. [...]

8. Conservar y promover sus prácticas de manejo de la biodiversidad y de su entorno natural. El Estado establecerá y ejecutará programas, con la participación de la comunidad, para asegurar la conservación y

utilización sustentable de la biodiversidad. [...]

12. Mantener, proteger y desarrollar los conocimientos colectivos; sus ciencias, tecnologías y saberes ancestrales; los recursos genéticos que contienen la diversidad biológica y la agrobiodiversidad; sus medicinas y prácticas de medicina tradicional, con inclusión del derecho a recuperar, promover y proteger los lugares rituales y sagrados, así como plantas, animales, minerales y ecosistemas dentro de sus territorios; y el conocimiento de los recursos y propiedades de la fauna y la flora. Se prohíbe toda forma de apropiación sobre sus conocimientos, innovaciones y prácticas. $[\ldots]$

36 GUDYNAS, Eduardo. Derechos de la naturaliza: ética biocéntrica y políticas ambientales.

37 GUDYNAS, Eduardo. Derechos de la naturaliza: ética biocéntrica y políticas ambientales. 
FORTES, Larissa Borges. A sustentabilidade e o pluralismo jurídico como principais elementos do novo constitucionalismo latino-americano. Revista Eletrônica Direito e Política, Programa de PósGraduação Stricto Sensu em Ciência Jurídica da UNIVALI, Itajaí, v.12, n.3, 30 quadrimestre de 2017. Disponível em: www.univali.br/direitoepolitica - ISSN 1980-7791

aplicação de tais direitos, Moraes e Freitas $^{38}$ trazem como exemplo o primeiro julgamento acerca dos direitos da Natureza, através de uma Ação Constitucional de Proteção à Natureza, julgada em 30 de março de 2011, pela Corte Provincial de Justiça de Loja, no Equador. Resumidamente, assim as autoras relatam

Na província de Loja, no Equador, ocorreu o primeiro julgamento que levou em consideração os direitos da Natureza, sendo o rio Vilcabamaba a parte do processo e com sentença em seu favor. Mais precisamente, tratou-se do caso de degradação do rio Vilcabamaba, importante fonte de subsistência para as populações locais.

$[\ldots]$

Diz o julgado: "dada a indiscutível importância da Natureza, e tendo em conta como fato notório seu evidente processo de degradação, a Ação de Proteção resulta na única via idônea e eficaz para por fim e remediar de maneira imediata um dano ambiental focalizado". É evidente aqui a eficácia de existir na norma constitucional proteção aos direitos da Mãe Terra. A existência de uma ação específica para a proteção desses direitos se faz como urgente frente ao ritmo de degradação no qual vivemos.

Resta evidente a enorme importância que tais direitos têm em uma Carta Política. Além da simbologia que representa a inclusão de direitos da Natureza, na perspectiva do biocentrismo - enquanto sujeito de direitos, no caso das constituições latino-americanas, esta perspectiva biocêntrica carrega a Filosofia Andina, bem como os ensinamentos a partir do paradigma do buen vivir.

O paradigma do buen vivir em Quechua (Equador) ou vivir bien em Aymara (Bolívia) surgem nas Constituições do Equador e da Bolívia como uma alternativa ao modelo ocidental até então imposto, em que pese esta última não tenha trazidos a questão dos direitos da Natureza da mesma forma como o Equador.

Conforme já referido anteriormente, a Constituição do Equador traz um capítulo especial para tratar dos derechos del buen vivir. Na Constituição da Bolívia, o

\footnotetext{
38 MORAES, Germana de Oliveira; FREITAS, Raquel Coelho. O novo constitucionalismo latinoamericano e o giro ecocêntrico da Constituição do Equador de 2008: os direitos de Pachamama e o bem viver (sumak kawsay). In: WOLKMER, Antônio Carlos. Constitucionalismo latino-americano: tendências contemporâneas, p. 116-117.
} 
FORTES, Larissa Borges. A sustentabilidade e o pluralismo jurídico como principais elementos do novo constitucionalismo latino-americano. Revista Eletrônica Direito e Política, Programa de PósGraduação Stricto Sensu em Ciência Jurídica da UNIVALI, Itajaí, v.12, n.3, 30 quadrimestre de 2017. Disponível em: www.univali.br/direitoepolitica - ISSN 1980-7791

vivir bien é trazido no artigo $313^{39}$, na parte relacionada à organização econômica. Leonel Junior ${ }^{40}$ assim refere sobre vivir bien:

Essas mudanças paradigmáticas serão fundamentais para que o Estado trilhe um caminho que considere e paute 0 vivir bien ou Sumaj qamaña na Bolívia. Esse conceito andino, crítico ao capitalismo e ao núcleo irracional da modernidade, traz valores comunitários da cosmovisão indígena, além de ressaltar a relação harmônica do homemmulher com a "mãe-terra". Logo, o vivir bien manifesta-se no modelo do Estado Plurinacional, no novo modelo territorial autonômico e no novo modelo econômico plural e comunitário.

Conforme bem colocado por Leonel Junior ${ }^{41}$, o vivir bien manifesta-se no Estado Plurinacional. Ao se observar o Capítulo Primeiro da Constituição da Bolívia, nos artigos $1^{0}$ ao $6^{042}$, é possível verificar todas as questões que estão relacionadas

\footnotetext{
39 Artículo 313. Para eliminar la pobreza y la exclusión social y económica, para el logro del vivir bien en sus múltiples dimensiones, la organización económica boliviana establece los siguientes propósitos:
}

1. Generación del producto social en el marco del respeto de los derechos individuales, así como de los derechos de los pueblos y las naciones.

2. La producción, distribución y redistribución justa de la riqueza y de los excedentes económicos.

3. La reducción de las desigualdades de acceso a los recursos productivos.

4. La reducción de las desigualdades regionales.

5. El desarrollo productivo industrializador de los recursos naturales.

6. La participación activa de las economías pública y comunitária en el aparato productivo.

40 LEONEL JUNIOR, Gladstone. O novo constitucionalismo latino-americano: um estudo sobre a Bolívia. Rio de Janeiro: Lumen Juris, 2015, p. 148.

41 LEONEL JUNIOR, Gladstone. O novo constitucionalismo latino-americano: um estudo sobre a Bolívia, p. 148.

42 Artícuo 1. Bolivia se constituye en un Estado Unitario Social de Derecho Plurinacional Comunitario, libre, independiente, soberano, democrático, intercultural, descentralizado y con autonomías. Bolivia se funda en la pluralidad y el pluralismo político, económico, jurídico, cultural y lingüístico, dentro del proceso integrador del país.

Artículo 2. Dada la existencia precolonial de las naciones y pueblos indígena originario campesinos y su dominio ancestral sobre sus territorios, se garantiza su libre determinación en el marco de la unidad del Estado, que consiste en su derecho a la autonomía, al autogobierno, a su cultura, al reconocimiento de sus instituciones y a la consolidación de sus entidades territoriales, conforme a esta Constitución y la ley.

Artículo 3. La nación boliviana está conformada por la totalidad de las bolivianas y los bolivianos, las naciones y pueblos indígena originário campesinos, y las comunidades interculturales y afrobolivianas que en conjunto constituyen el pueblo boliviano. 
FORTES, Larissa Borges. A sustentabilidade e o pluralismo jurídico como principais elementos do novo constitucionalismo latino-americano. Revista Eletrônica Direito e Política, Programa de PósGraduação Stricto Sensu em Ciência Jurídica da UNIVALI, Itajaí, v.12, n.3, 30 quadrimestre de 2017. Disponível em: www.univali.br/direitoepolitica - ISSN 1980-7791

ao modelo de estado plurinacional, considerando as diversas nacionalidades, povos, idiomas, símbolos, etc.

Já no Capítulo Segundo, entre os artigos 70 ao 10043 , verifica-se a organização dos princípios, valores e fins do Estado Plurinacional da Bolívia, onde se faz presente o paradigma do vivir bien, sendo descrito, inclusive, a denominação existente dentre os diversos povos que coexistem no território boliviano.

Importante destacar, como bem refere Gudynas ${ }^{44}$, que a cosmovisão andina não representa um retrocesso ou um retorno ao passo pré-colonial, tampouco um isolamento às questões contemporâneas. A Filosofia Andina não se apresenta de forma fechada às demais visões, ao contrário, a cosmovisão andina pressupõe a existência de um diálogo, permitindo, inclusive, que algumas visões ocidentais possam aprender se aliado com os saberes indígenas.

Inegavelmente, o novo constitucionalismo latino-americano, através de constituições como a do Equador e da Bolívia, tenta concretizar um giro ecocêntrico. As referidas constituições trazem em seus textos toda sabedoria dos povos originários, com novos referenciais epistemológicos - Pachamama e Buen

Artículo 4. El Estado respeta y garantiza la libertad de religión y de creencias espirituales, de acuerdo con sus cosmovisiones. El Estado es Independiente de la religión.

Artículo 5. I. Son idiomas oficiales del Estado el castellano y todos los idiomas de las naciones y pueblos indígena originario campesinos, [...]

43 Artículo 7. La soberanía reside en el pueblo boliviano, se ejerce de forma directa y delegada. De ella emanan, por delegación, las funciones y atribuciones de los órganos del poder público; es inalienable e imprescriptible.

Artículo 8. I. El Estado asume y promueve como principios ético-morales de la sociedad plural: ama qhilla, ama llulla, ama suwa (no seas flojo, no seas mentiroso ni seas ladrón), suma qamaña (vivir bien), ñandereko (vida armoniosa), teko kavi (vida buena), ivi maraei (tierra sin mal) y qhapaj ñan (camino o vida noble).

II. El Estado se sustenta en los valores de unidad, igualdad, inclusión, dignidad, libertad, solidaridad, reciprocidad, respeto, complementariedad, armonía, transparencia, equilibrio, igualdad de oportunidades, equidad social y de género en la participación, bienestar común, responsabilidad, justicia social, distribución y redistribución de los productos y bienes sociales,

para vivir bien.

44 GUDYNAS, Eduardo. Derechos de la naturaliza: ética biocéntrica y políticas ambientales. 
FORTES, Larissa Borges. A sustentabilidade e o pluralismo jurídico como principais elementos do novo constitucionalismo latino-americano. Revista Eletrônica Direito e Política, Programa de PósGraduação Stricto Sensu em Ciência Jurídica da UNIVALI, Itajaí, v.12, n.3, 30 quadrimestre de 2017. Disponível em: www.univali.br/direitoepolitica - ISSN 1980-7791

Vivir ou Vivir Bien -, fundamentais para caminhar no horizonte da Sustentabilidade. É o que explica Marques Junior ${ }^{45}$ :

Os novos referenciais epistemológicos da Pachamama (Madre Tierra) e do Buen Vivir (Sumak Kawsay) são abordados a partir da visão analítica, de maneira a demonstrar como a proposta de reconfiguração nas relações entre homens e natureza pode proporcionar a sustentabilidade, conformando o processo econômico a partir da preservação da cultura e dos saberes tradicionais, num processo não predatório de aproveitamento de recursos naturais, atrelado aos saberes dos povos ancestrais.

A proposta de relevar a colonialidade na epistemologia do Estado e movê-lo em direção a novas bases, o Novo Constitucionalismo Democrático Latino-Americano reconhece a abertura para os valores oriundos dos povos ancestrais. Seu desafio, no entanto, está em concretizar suas aspirações e na operacionalização das novidades declaradas nos textos constitucionais.

Conforme indica Gudynas ${ }^{46}$, as constituições da Bolívia e do Equador incorporaram a Sustentabilidade como um horizonte a ser seguido, o que pode ser observado nos diversos artigos das referidas constituições, onde aparece a palavra "sustentabilidade" ou "sustentável", além da própria ideia de mudança de paradigma a partir da cosmovisão andina, que pressupõe a ideia de Sustentabilidade.

Gudynas $^{47}$ ainda indica as várias correntes que tratam da Sustentabilidade, explicando existir uma divisão "escalas" dentro da categoria Sustentabilidade: i) a débil - se encontra temas ambientais, no entanto, na visão antropocêntrica; ii) a forte - faz da Natureza e sua preservação um negócio, carrega um viés antropocêntrico; e a iii) super forte - o exemplo seria a Constituição do Equador,

\footnotetext{
45 MARQUES JUNIOR, William Paiva. A epistemologia emancipatória, inclusiva e participativa do novo constitucionalismo democrático latino-americano. In: MORAES, Germana de Oliveira (Org.). Constitucionalismo democrático e integração da América do Sul. Curitiba: CRV, 2014, p. 100-116, p. 105.

46 GUDYNAS, Eduardo. Derechos de la naturaliza: ética biocéntrica y políticas ambientales.

47 GUDYNAS, Eduardo. Derechos de la naturaliza: ética biocéntrica y políticas ambientales.
} 
FORTES, Larissa Borges. A sustentabilidade e o pluralismo jurídico como principais elementos do novo constitucionalismo latino-americano. Revista Eletrônica Direito e Política, Programa de PósGraduação Stricto Sensu em Ciência Jurídica da UNIVALI, Itajaí, v.12, n.3, 30 quadrimestre de 2017. Disponível em: www.univali.br/direitoepolitica - ISSN 1980-7791

que busca novos estilos de desenvolvimento, prevê direitos da Natureza e possui como ideal o buen vivir.

Tem-se, portanto, que o novo constitucionalismo latino-americano traz elementos inovadores no sentido de se buscar outras formas de desenvolvimento e combate aos problemas recorrentes no continente latino. Tais elementos são transformadores, na medida em que são concebidos a partir do olhar local, das reivindicações populares, dos povos indígenas, enfim, daqueles que foram excluídos dos processos constituintes até então.

Marques Junior ${ }^{48}$ traz o elenco de novos elementos trazidos a partir do novo constitucionalismo latino-americano, contemplados no presente texto como fundamentos de novo movimento:

Os aspectos epistemológicos inovadores presentes no Novo Constitucionalismo Democrático Latino-Americano consistem em: (1) resgate de valores, tais como a solidariedade, da cooperação, da harmonia e da complementaridade como princípios informativos; (2) pluralismo jurídico representados pelo reconhecimento da natureza como sujeito de dignidade e de direitos o que faz surgir uma nova racionalidade não antropocêntrica; (3) valorização do direito oriundo dos povos indígenas; (4) materialização de instrumentos de democracia participativa e a consequente valorização da vontade popular como elemento central estrutura políticonormativa.

Observa-se, pois, uma série de elementos novos e importantes para uma verdadeira transformação no modelo de Estado e de organização política, garantindo espaços de participação popular, bem como de consolidação e aplicação de saberes dos povos tradicionais.

Tais elementos fazem com que os processos político-jurídico na América Latina sejam pioneiros no que tange à construção de alternativas ao modelo de desenvolvimento apresentados pelos continentes europeus e norte-americanos.

\footnotetext{
48 MARQUES JUNIOR, William Paiva. A epistemologia emancipatória, inclusiva e participativa do novo constitucionalismo democrático latino-americano. In: MORAES, Germana de Oliveira (Org.). Constitucionalismo democrático e integração da América do Sul, p. 102-103.
} 
FORTES, Larissa Borges. A sustentabilidade e o pluralismo jurídico como principais elementos do novo constitucionalismo latino-americano. Revista Eletrônica Direito e Política, Programa de PósGraduação Stricto Sensu em Ciência Jurídica da UNIVALI, Itajaí, v.12, n.3, 30 quadrimestre de 2017. Disponível em: www.univali.br/direitoepolitica - ISSN 1980-7791

Os ensinamentos advindos dos povos indígenas originários, a partir do paradigma do buen vivir ou vivir bien são fundamentais para a construção de um Estado onde a busca por desenvolvimento seja realizada de maneira diversa, com respeito e harmonia, com a Mãe Terra (Pachamama) ou Natureza, deslocando a perspectiva ocidental como central dos povos desde nuestra América ${ }^{49}$.

\section{CONSIDERAÇÕES FINAIS}

A Filosofia Andina, da qual compartilha boa parte dos povos indígenas originários da América Latina, se expressa através da cultura do vivir bien/buen vivir. Observou-se, a partir da presente pesquisa, que o paradigma do bem viver pressupõe harmonia e equilíbrio entre todos os seres habitantes deste Planeta, afastando-se, portanto, da visão antropocêntrica e, por consequência, aproximando-se de uma visão biocêntrica.

Recentemente, os Estados da Bolívia e do Equador, através de suas novas constituições, preocuparam-se em resgatar as bases culturais decorrentes da cultura indígena, reconhecendo e valorizando a existência dos povos tradicionais. Os referidos textos constitucionais trouxeram elementos inovadores, elementos estes que vão ao encontro do que propõe a Sustentabilidade.

As constituições da Bolívia e do Equador representam um verdadeiro marco no novo Constitucionalismo Latino-Americano, reconhecendo-se a existência de estados multiétnicos, plurinacionais, concretizando um verdadeiro giro descolonial e ecocêtrico, caminhando no horizonte da Sustentabilidade.

Vanguardistas, tais constituições colocaram os saberes dos povos tradicionais e europeus num mesmo nível epistemológico, o que representa a abertura ao diálogo cultural, sem sobreposições e subordinações. Vale lembrar que os saberes indígenas restaram encobertos até então, sendo que tais povos estavam

49 Termo utilizado por Gladstone Leonel Junior, no texto LEONEL JUNIOR, Gladstone. Soberania popular e constituinte exclusiva: uma visão desde nuestra América. In: RIBAS, Luiz Otávio. Constituinte exclusiva: um outro sistema político é possível. São Paulo: Expressão Popular, 2014, p. 95-103. 
FORTES, Larissa Borges. A sustentabilidade e o pluralismo jurídico como principais elementos do novo constitucionalismo latino-americano. Revista Eletrônica Direito e Política, Programa de PósGraduação Stricto Sensu em Ciência Jurídica da UNIVALI, Itajaí, v.12, n.3, 30 quadrimestre de 2017. Disponível em: www.univali.br/direitoepolitica - ISSN 1980-7791

excluídos de qualquer construção normativa dentro de seu próprio Estadoterritório.

Sendo assim, mostra-se possível verificar que a plurinacionalidade - elemento este contido nas constituições do Equador e da Bolívia - é de extrema importância nas questões atinentes à soberania popular, bem como na vivacidade da própria democracia, na medida em que abre espaços de participação de todos os povos, nacionalidades e comunidades que coexistem nos referidos países.

Pioneiramente, o Equador estabeleceu os Direitos da Natureza ou Pachamama como pressuposto de Sustentabilidade em sua Constituição. Tais direitos, até então reconhecidos num viés estritamente antropocêntrico, encontram-se numa nova configuração: a Natureza ou Pachamama enquanto sujeito de direitos. Destaca-se que o viés biocêntrico carrega em sua origem a mudança proposta pelo próprio paradigma do buen vivir (sumak kawsay), oriundo dos povos indígenas andinos da região do Equador, os Quechua.

A partir de tais indagações, buscou-se responder ao seguinte problema de pesquisa: Quais os fundamentos que o Constitucionalismo Latino-Americano traz como inovação para caminhar no horizonte da Sustentabilidade?

Procurou-se analisar as contribuições das Constituições da Bolívia e do Equador, o que propiciou verificar a importância da concretização do pluralismo cultural e jurídico contidos em tais textos normativos. Verificou-se, a partir desse elemento, a importância da participação dos povos indígenas, movimentos sociais e sociedade civil em geral, na construção dos processos que decorreram o novo constitucionalismo.

Tais processos mostraram que, nesse momento histórico importante da América Latina, os povos e comunidades até então excluídos de qualquer processo político, não participaram enquanto coadjuvantes, mas enquanto atores principais do referido processo. 
FORTES, Larissa Borges. A sustentabilidade e o pluralismo jurídico como principais elementos do novo constitucionalismo latino-americano. Revista Eletrônica Direito e Política, Programa de PósGraduação Stricto Sensu em Ciência Jurídica da UNIVALI, Itajaí, v.12, n.3, 30 quadrimestre de 2017. Disponível em: www.univali.br/direitoepolitica - ISSN 1980-7791

Nesse passo, procurou-se analisar as inovações marcantes que o novo constitucionalismo latino-americano trouxe: a plurinacionalidade e os direitos da Natureza ou Pachamama. Conclui-se que tais elementos inovadores são fundamentais para se pensar um ideal de Sustentabilidade.

Estudou-se os artigos constantes na Constituição da Bolívia e do Equador, com relação à plurinacionalidade e aos direitos da Natureza, e de que forma tais direitos possuem aplicabilidade e pressupõe um repensar no próprio modelo de Estado.

Verificou-se que tais elementos inovadores são, em verdade, fundantes do próprio movimento do novo constitucionalismo latino-americano, necessários para a composição de uma perspectiva plural e biocêntrica, além da descolonização que tal movimento constitucional proporcionou.

Sendo assim, constatou-se que esses fundamentos do cenário latino-americano contribuem, inevitavelmente, para cenários de diálogo multicultural. Observou-se que nesse momento histórico da América Latina, o olhar para raízes dos povos indígenas originários é o melhor caminho para o futuro, já que o paradigma do Buen Vivir ou Vivir Bien já trilha no horizonte da Sustentabilidade muito antes de conhecer a referida palavra.

\section{REFERÊNCIA DAS FONTES CITADAS}

ACOSTA, Alberto; MARTÍNEZ, Esperanza (Org.). La naturaleza con derechos: de la filosofía a la política. Quito, Equador: Ediciones Abya-Yala, 2011.

AQUINO, Sergio R. F. de. O direito em busca de sua humanidade: diálogos errantes. Curitiba: CRV, 2014.

BOFF, Leonardo. Ética da vida: a nova centralidade. Rio de Janeiro: Record, 2009.

BOSSELMANN, Klaus. O princípio da sustentabilidade: transformando direito e governança. Tradução de Phillip Gil França. São Paulo: Editora Revista dos Tribunais, 2015.

CONSTITUICIÓN POLÍTICA DEL ESTADO PLURINACIONAL DE BOLIVIA. Disponível em: <http://www.gacetaoficialdebolivia.gob.bo/edicions/buscar>. Acesso em 31 maio 2015. 
FORTES, Larissa Borges. A sustentabilidade e o pluralismo jurídico como principais elementos do novo constitucionalismo latino-americano. Revista Eletrônica Direito e Política, Programa de PósGraduação Stricto Sensu em Ciência Jurídica da UNIVALI, Itajaí, v.12, n.3, 30 quadrimestre de 2017. Disponível em: www.univali.br/direitoepolitica - ISSN 1980-7791

CONSTITUICIÓN DE LA REPÚBLICA DEL ECUADOR. Disponível em: <http://www.stf.jus.br/repositorio/cms/portalStfInternacional/newsletterPortalIn ternacionalFoco/anexo/ConstituicaodoEquador.pdf>. Acesso em 29 set 2015.

CORTINA, Adela. Cidadãos do mundo: para uma teoria da cidadania. Tradução de Silvana Cobucci Leite. São Paulo: Edições Loyola, 2005.

GALEANO, Eduardo. As veias abertas da América Latina. Tradução de Sergio Faraco. Porto Alegre (RS): L\&PM Pocket, 2012.

GUDYNAS, Eduardo. Derechos de la naturaliza: ética biocéntrica y políticas ambientales. Lima: CLAES, 2014.

LATOUCHE, Sergio. Pequeno tratado do decrescimento sereno. Tradução de Claudia Berliner. São Paulo: Editora WMF Martins Fontes, 2009.

LEFF, Enrique. Epistemologia ambiental. Tradução de Sandra Valenzuela. 5. ed. São Paulo: Cortez, 2011.

LEONEL JUNIOR, Gladstone. O novo constitucionalismo latino-americano: um estudo sobre a Bolívia. Rio de Janeiro: Lumen Juris, 2015.

LEONEL JUNIOR, Gladstone. Soberania popular e constituinte exclusiva: uma visão desde nuestra América. In: RIBAS, Luiz Otávio. Constituinte exclusiva: um outro sistema político é possível. São Paulo: Expressão Popular, 2014 , p. $95-103$.

MAMANI, Fernando H. Buen vivir/ Vivir bien: Filosofía, políticas, estrategias y experiencias regionales andinas. Peru: CAOI, 2010.

MARQUES JUNIOR, William Paiva. A epistemologia emancipatória, inclusiva e participativa do novo constitucionalismo democrático latinoamericano. In: MORAES, Germana de Oliveira (Org.). Constitucionalismo democrático e integração da América do Sul. Curitiba: CRV, 2014, p. 100-116.

MORAES, Germana de Oliveira; FREITAS, Raquel Coelho. o novo constitucionalismo latino-americano e o giro ecocêntrico da Constituição do Equador de 2008: os direitos de Pachamama e o bem viver (sumak kawsay). In: WOLKMER, Antônio Carlos. Constitucionalismo latino-americano: tendências contemporâneas. Curitiba: Juruá, 2013, p. 103-124.

PRONER, Carol. O Estado Plurinacional e a Nova Constituição Boliviana: Contribuições da experiência boliviana ao debate dos limites ao modelo democrático liberal. In: WOLKMER, Antônio Carlos. Constitucionalismo latinoamericano: tendências contemporâneas. Curitiba: Juruá, 2013.

WOLKMER, Antônio Carlos. Pluralismo Jurídico: Fundamentos de uma nova cultura no Direito. 3 ed. São Paulo: Alfa-Omega, 2001. 
FORTES, Larissa Borges. A sustentabilidade e o pluralismo jurídico como principais elementos do novo constitucionalismo latino-americano. Revista Eletrônica Direito e Política, Programa de PósGraduação Stricto Sensu em Ciência Jurídica da UNIVALI, Itajaí, v.12, n.3, 30 quadrimestre de 2017. Disponível em: www.univali.br/direitoepolitica - ISSN 1980-7791

WOLKMER, Antônio Carlos, FAGUNDES, Lucas Machado. Tendências contemporâneas do constitucionalismo latino-americano: Estado plurinacional e pluralismo jurídico. In: Pensar, Fortaleza, v. 16, n. 2, p. 371-408, jul./dez. 2011.

Submetido em: junho de 2017

Aprovado em: agosto de 2017 